Case Report

\title{
The Effectiveness of One Visit Vital Pulpotomy in Primary Teeth
}

\author{
Henri Hartman \\ Dentistry Studies Program \\ Faculty of Medicine University of Jenderal Achmad Yani \\ Terusan Jend. Sudirman PO. BOX 148, Cimahi 40533, Indonesia \\ Email: henri.hartman@lecture.unjani.ac.id
}

\begin{abstract}
Primary teeth caries is a common problem in pre-school children; commonly caused by high sugar consumption dan food impaction. Primary teeth caries in posterior region can cause painful attack on child and needs root canal treatment with many treatment visits. We reported pulp therapy on 8 years old child with irreversible pulpitis 54, treated by one visit vital formocresol pulpotomy. Patient came with acute condition, pain on upper posterior area. Intra oral examination showed caries on teeth 54 with pulp involved and caries dentin on 55. Vitality test (+), mobility (-), percussion $(+)$, and no sign of soft tissue abnormality. Vital pulpotomy was chosen for 54 treatment, bleeding control with formocresol, obturation with Zinc Oxide Eugenol (ZOE), and finally restoration with stainless steel crown, all treatment was done in one visit. Four month evaluation showed no complaint reported. We concluded one visit pulpotomy for pulp therapy showed optimum result in primary tooth and reduce the necessity of multiple treatment visits.
\end{abstract}

Keywords: formocresol, primary teeth, stainless steel crown, vital pulpotomy 


\title{
Efektivitas Pulpotomi Vital Satu Kali Kunjungan pada Gigi Sulung
}

\author{
Henri Hartman \\ Program Studi Kedokteran Gigi \\ Fakultas Kedokteran Universitas Jenderal Achmad Yani \\ Terusan Jend. Sudirman PO. BOX 148, Cimahi 40533, Indonesia \\ Email: henri.hartman@lecture.unjani.ac.id
}

\begin{abstract}
Abstrak
Karies pada gigi sulung posterior merupakan masalah yang umum terjadi pada usia anak sekolah. Penyebabnya antara lain konsumsi gula berlebih dan tersangkutnya makanan di antara gigi. Karies di gigi posterior yang meluas hingga kamar pulpa sering menganggu fungsi pengunyahan dan menyebabkan rasa sakit sehingga memerlukan perawatan saluran akar yang memerlukan waktu lama. Artikel ini melaporkan perawatan saluran akar disertai restorasi stainless steel crown (SSC) satu kali kunjungan pada anak laki-laki usia 8 tahun dengan diagnosis irreversible pulpitis gigi 54. Pasien datang bersama orang tua dengan keluhan sakit spontan di gigi belakang kanan rahang atas. Hasil pemeriksaan intra oral memperlihatkan karies hingga ke dalam pulpa pada bagian distal oklusal gigi 54 dan karies hingga dentin pada gigi 55. Uji vitalitas (+), kegoyangan (-), perkusi (+), jaringan sekitar tidak ada kelainan. Perawatan dilakukan dengan teknik pulpotomi vital dengan formokresol, pengisian kamar pulpa dengan zinc oxide eugenol (ZEO), restorasi utama dengan SSC; keseluruhannya dilakukan dalam satu kali kunjungan. Evaluasi 4 bulan kemudian menunjukkan tidak ada keluhan. Laporan kasus ini memperlihatkan keberhasilan perawatan endodontik satu kali kunjungan pada gigi sulung.
\end{abstract}

Kata kunci: formokresol, gigi sulung, pulpotomi vital, stainless steel crown 
Case Report

\section{Pendahuluan}

Tujuan utama perawatan kesehatan gigi anak adalah mencegah terjadinya berbagai macam penyakit yang ada di dalam rongga mulut. Karies gigi merupakan kondisi kelainan yang paling umum terjadi pada usia anak dan menjadi permasalahan yang penting dalam kesehatan masyarakat. $^{1,2}$

Karies yang terus meluas hingga ke kamar pulpa akan menimbulkan rasa sakit pada anak sehingga menurunkan nafsu makan bahkan terkadang mengganggu rasa percaya diri pasien. Gigi sulung yang telah rusak hingga ke area pulpa dapat dipertahankan melalui perawatan baik dilakukan secara satu kali kunjungan ataupun melalui beberapa kali pertemuan perawatan sehingga gigi sulung tetap dapat berfungsi sampai digantikan oleh gigi dewasa.,

Perawatan pulpa gigi sulung dapat dilakukan dengan beberapa cara diantaranya pulpotomi dan pulpektomi. Pulpektomi merupakan perawatan saluran akar yang dilakukan dengan menggunakan jarum endodontik untuk mencegah bakteri meluas hingga area periapikal. Pulpektomi dilakukan apabila perdarahan di area pulpa tidak bisa teratasi dan menjadi pilihan utama apabila terdapat lesi periapikal. Sementara itu, pulpotomi merupakan teknik perawatan kamar pulpa tanpa melakukan perawatan hingga ke ujung akar dengan tujuan mempertahankan vitalitas gigi. Teknik pulpotomi menjadi pilihan yang efektif untuk digunakan pada gigi sulung dan dapat dilakukan dalam satu kali kunjungan dengan menggunakan bahan medikasi yang sesuai. Pemilihan teknik perawatan kamar pulpa itu sendiri tergantung dari kondisi kamar pulpa yang sesuai indikasi perawatan. ${ }^{4-6}$

Teknik pulpotomi vital dalam satu kali kunjungan telah lama dilakukan dan dilaporkan memberikan hasil yang efektif dalam mempertahankan struktur gigi sulung. Pada umumnya, disarankan penggunaan stainless steel crown (SSC) untuk restorasi utama setelah perawatan pulpotomi. $^{6-9}$

SSC memiliki keunggulan dalam segi resistensi maupun retensi suatu restorasi. Penempatannya yang tidak terlalu lama dan dapat dilakukan dalam satu kali kunjungan akan sangat memudahkan dokter gigi dan juga meningkatkan kepuasan pasien. Hal ini disebabkan karena pasien tidak perlu melakukan kunjungan ke dokter gigi secara berulang kali. ${ }^{6,7,10}$ Namun demikian, SSC memiliki kekurangan dalam segi estetika, karena warnanya yang berupa logam membuat pasien tidak mampu memperoleh estetika yang memuaskan.

\section{Laporan kasus}

Seorang anak laki-laki, usia 8 tahun, datang ke klinik dokter gigi dengan keluhan sakit berdenyut pada daerah kanan atas belakang sejak satu hari yang lalu. Sakit terasa tiba-tiba, dan bertambah hebat pada saat mengunyah makanan. Hasil pemeriksaan intrat oral memperlihatkan 
Case Report

karies mencapai pulpa pada gigi 54 bagian proksimal disto-oklusal dan karies dentin gigi 55 bagian proksimal mesio-oklusal (Gambar 1).
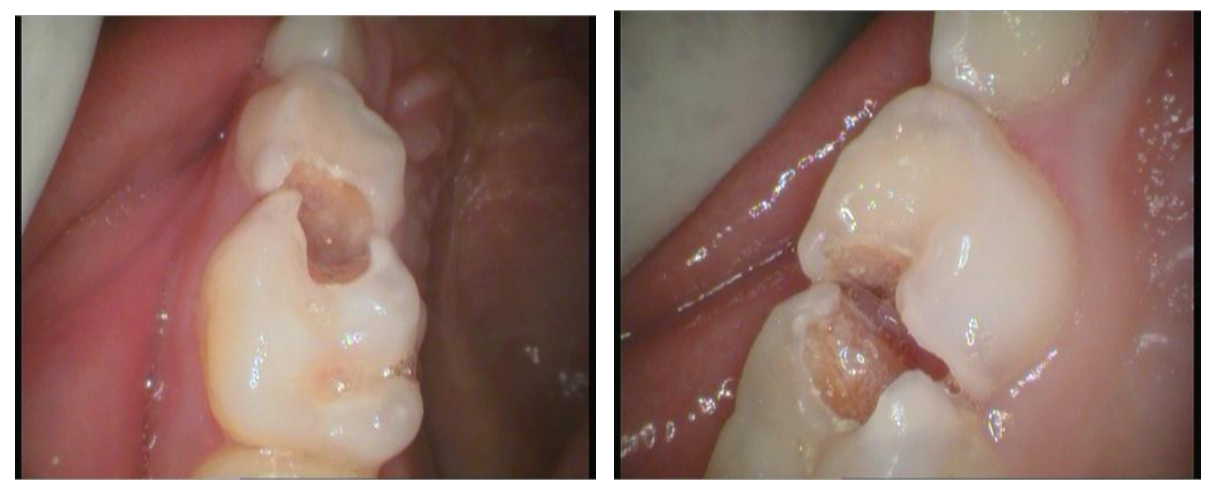

Gambar 1 Karies Mencapai Pulpa 54, Karies Dentin 55

Tidak ada riwayat medis yang dilaporkan oleh orang tua pasien. Pasien tidak pernah menerima perawatan kesehatan gigi dan mulut pada waktu lampau. Pasien mampu berkomunikasi dan bekerja sama dengan baik dalam menerima semua informasi mengenai kondisi gigi yang mengalami kerusakan.

Jaringan sekitar gigi dalam batas normal, tidak ditemukan adanya fistula (sinus tract). Hasil uji vitalitas memperlihatkan gigi dalam kondisi vital. Hasil pemeriksaan dengan explorer ditemukan karies telah mencapai pulpa ditandai dengan adanya darah yang keluar dari rongga pulpa. Jaringan periodontal tidak memiliki kelainan dan berada dalam kondisi sehat. Gigi 54 tidak memiliki kegoyangan, demikian juga dengan gigi 55.

Kondisi gigi dan juga kondisi psikologis pasien menunjukkan indikasi untuk dilakukan tindakan pulpotomi vital dalam satu kali kunjungan pada gigi 54. Adapun, langkah-langkah perawatan yang dilakukan adalah pemberian anastesi lokal terlebih dahulu pada area gigi 54 dengan teknik infiltrasi dan dilanjutkan dengan teknik intrapulpa, pembukaan akses pulpa menggunakan bur intan berbentuk bundar dan bur akses kamar pulpa. Semua atap kamar pulpa dibersihkan dan tidak terdapat atap kamar pulpa, pembuangan jaringan pulpa menggunakan ekskavator steril yang tajam dan dilanjutkan dengan slow speed bur, irigasi kamar pulpa dengan $\mathrm{NaCl} 0,9 \%$ / larutan fisiologis selama 3 menit, aplikasi Buckley's Formokresol menggunakan kapas bersih selama 4 menit untuk menghentikan perdarahan (Gambar 2).

Setelah perdarahan pulpa terhenti, langkah selanjutnya adalah melakukan pengisian (obturasi) kamar pulpa menggunakan semen zinc oxide eugeunol (ZEO) (Kalzinol, Dentsply) secara merata pada kamar pulpa (Gambar 3). Aplikasi semen liner dengan menggunakan glass ionomer (GC Fuji 9) hingga menutupi seluruh hasil preparasi atap pulpa. Preparasi gigi 55 untuk restorasi 
Case Report

stainless steel crown (SSC) (gambar 4).

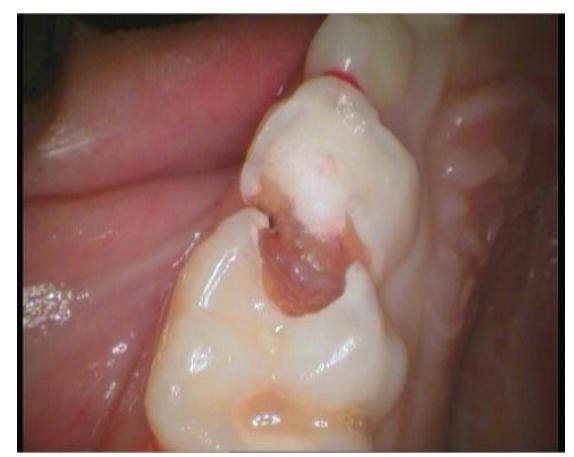

Gambar 2 Aplikasi Buckley's Formokresol ke dalam Ruang Pulpa dengan Kapas Bersih selama 4 Menit

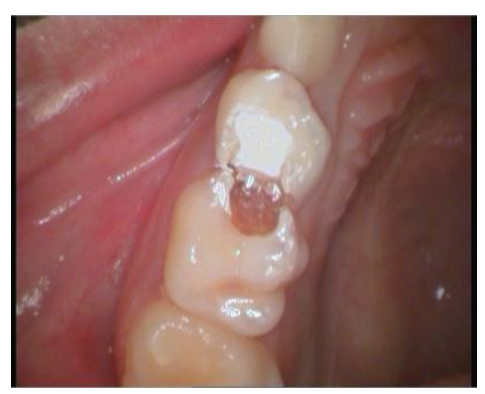

Gambar 3 Aplikasi Zinc Oxide Eugenol (Zoe) ke dalam Kavitas setelah Perdarahan Berhenti
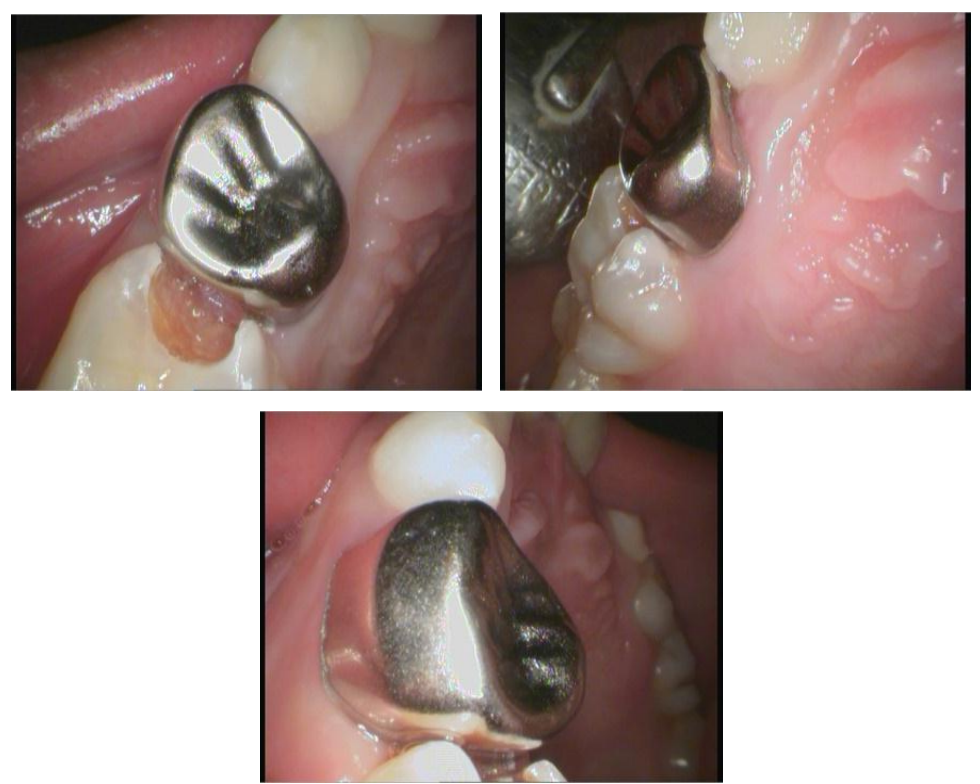

Gambar 4 Aplikasi Restorasi SSC pada Gigi 54 
Case Report

Setelah restorasi 54 selesai, selanjutnya dilakukan restorasi resin komposit pada gigi 55. Restorasi pada gigi 55 dilakukan pada saat evaluasi perawatan di kunjungan berikutnya. Pasien dianjurkan untuk pemeriksaan ulang dalam waktu satu minggu setelah perawatan, namun pasien datang setelah 4 bulan pasca perawatan. Hasil evaluasi memperlihatkan restorasi masih dalam keadaan baik dan tidak ada keluhan dari pasien mengenai hasil perawatan, jaringan lunak dalam batas normal dan tidak ditemukan adanya kelainan periapikal terlihat dari hasil foto $x$-ray periapikal (Gambar 5).
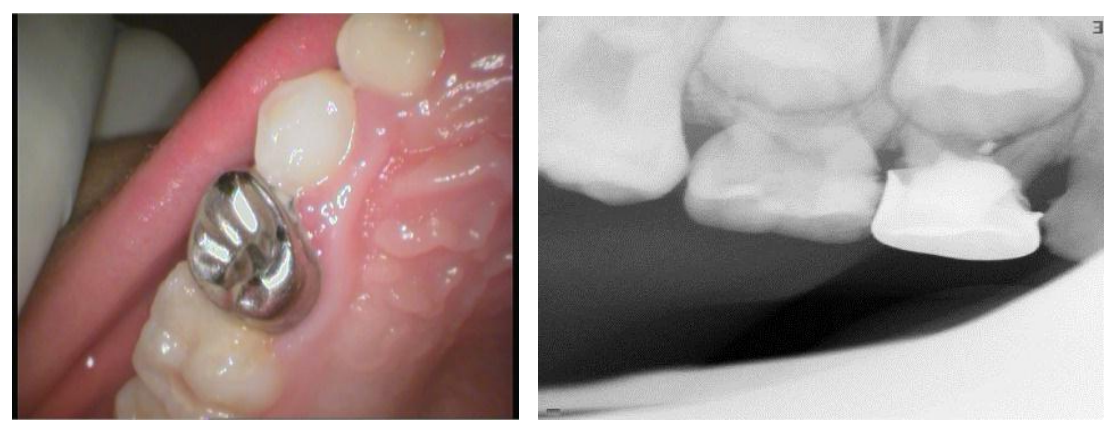

Gambar 5 Hasil Evaluasi 4 Bulan Pasca Perawatan

\section{Diskusi}

Pulpotomi merupakan salah satu perawatan pulpa dengan cara membuang bagian pulpa di ruang pulpa dan dilanjutkan dengan penempatan bahan yang biocompatible serta mampu mempertahankan vitalitas gigi. ${ }^{5,6,11,12}$

Pulpotomi dilakukan pada gigi yang memiliki pulpa sehat dengan gejala pulpitis ireversible dan karies mencapai pulpa. Gigi yang dilakukan pulpotomi tidak boleh memiliki kelainan periapikal. $^{1,4,13}$

Pulpotomi dilakukan pada gigi sulung yang memiliki kerusakan terlalu luas namun tanpa disertai kelainan periapikal. Bagian pulpa koronal diamputasi dan dipertahankan vitalitasnya menggunakan bahan yang sesuai seperti Buckley's formokresol dan ferric sulfate, dapat juga dengan sodium hipoklorit, kalsium hidroksida, dan Mineral Trioxide Aggregate (MTA). ${ }^{1,4,5,11,14}$ MTA merupakan bahan material terkini yang memiliki tingkat kesuksesan lebih besar dibandingkan kalsium hidroksida. Selain bahan tersebut, dapat pula dilakukan amputasi dengan electrosurgery. Beberapa penelitian lebih menyarankan untuk menggunakan ferric sulfate untuk menghindari toksisitas dari formokresol. ${ }^{5,15-17}$ Langkah selanjutnya adalah pengisian (obturasi) kamar pulpa dengan bahan yang sesuai misalnya zincloxide eugenol. Bahan pengisi lain yang dapat digunakan adalah Vitapex ${ }^{\mathrm{TM}}$ yang mengandung $\mathrm{Ca}(\mathrm{OH})_{2}$ dan pasta iodoform, MTA maupun material baru seperti Biodentin. ${ }^{6,18,19}$ Restorasi utama yang disarankan adalah SSC (Gambar 6), 


\section{Case Report}

namun apabila masih terdapat struktur gigi yang cukup, maka restorasi dapat dilanjutkan dengan menggunakan bahan resin komposit maupun amalgam, terutama bila gigi yang dirawat memiliki usia yang kurang dari dua tahun lagi. ${ }^{6,14,20,21}$

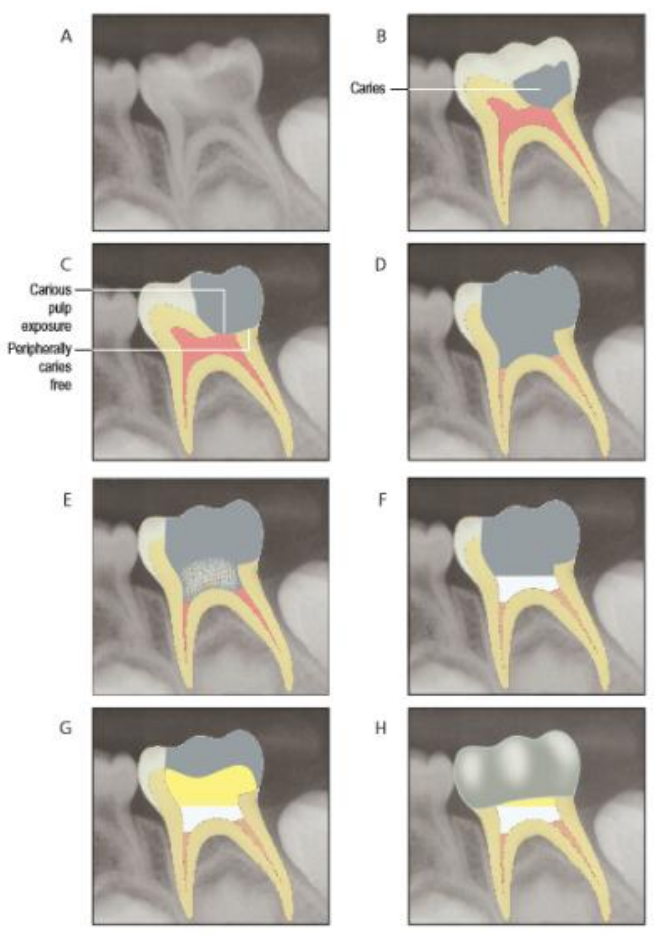

\footnotetext{
Gambar 6 Prosedur Perawatan Pulpotomi pada Gigi Sulung ${ }^{19}$

Keterangan :

A-B : lesi karies yang mencapai pulpa.

C-D : pembukaan kamar pulpa.

E : aplikasi formocresol/calcium hidroksida dan lain sebagainya.

F : aplikasi ZOE.

$\mathrm{G}$ : aplikasi semen base (liner). H: restorasi dengan SSC. ${ }^{14}$
}

Pada pasien kami, pulpotomi dilakukan menggunakan formokresol karena penggunaannya yang reatif mudah dan tidak memerlukan biaya yang lebih mahal bagi pasien, adapun pilihan perawatan lainnya adalah berupa pulpektomi vital yang juga dapat dilakukan dalam satu kali kunjungan. ${ }^{7,22}$ Pengisian kamar pulpa dilakukan menggunakan ZEO (Kalzinol, Dentsply, USA). Evaluasi kamar pulpa umumnya dilakukan setelah 3 bulan perawatan untuk mengevaluasi ada tidaknya kelainan di area ujung akar gigi. Namun, pasien pada kasus ini baru dapat melakukan evaluasi di bulan ke-4. Perawatan pulpotomi umumnya memerlukan evaluasi rutin selama 3-6 bulan dan dilanjutkan hingga 2 tahun paska perawatan. Akan tetapi, pada pasien kasus ini dapat melakukan evaluasi setelah 4 bulan paska perawatan. Hasil evaluasi 4 bulan tersebut tidak menunjukkan adanya keluhan maupun kelainan baik secara klinis maupun radiologis serta restorasi SSC masih dalam kondisi baik tanpa ada kebocoran. Hasil radiologi periapikal memperlihatkan 
Case Report

restorasi dalam kondisi yang baik, tidak ditemukan resorpsi internal, tidak ada permasalahan periodontal, tidak ada kegoyangan, dan tidak terdapat kelainan periapikal.

\section{Simpulan}

Penggunaan teknik pulpotomi vital yang dilanjutkan restorasi Stainless steel crown dapat dilakukan dalam satu kali kunjungan dan mampu memberikan hasil yang optimal dalam mengatasi keluhan sakit gigi pada pasien anak.

\section{Daftar Pustaka}

1 Kisby L. Vital pulp therapy in primary teeth: An update. Dent Today. 2016;35:1-9.

2 Pedroso L, Zucuni C, Yassue J, Santos BZ. Oral rehabilitation of patient with severe early childhood caries : a case report. South Brazilian Dent J. 2014;11:100-6.

3 Marquezin MCS, Zancopé BR, Pacheco LF, Gavião MBD, Pascon FM. Aesthetic and functional rehabilitation of the primary dentition affected by amelogenesis imperfecta. Case Rep Dent. 2015;11:1-6.

4 Seale NS, Coll J. Vital pulp therapy for the primary dentition. Gen Dent. 2010;3:194-200.

5 Casas MJ, Kenny DJ, Johston DH, Judd PL. Long-term outcomes of primary molar ferric sulfate pulpotomy and root canal therapy. Pediatr Dent. 2004; 26:44-8.

6 Council on Clinical Affairs American Academy of Pediatric Dentistry. Guideline on pulp therapy for primary and immature permanent teeth. Pediatr Dent. 2015;37:244-52.

7 Farooq NS, Coll JA, Kuwabara A, Shelton P. Success rates of formocresol pulpotomy and indirect pulp therapy in the treatment of deep dentinal caries in primary teeth. Pediatr Dent. 2000;22:278-86.

8 Rodd HD, Waterhouse PJ, Fuks AB, Fayle SA, Moffat MA. UK national clinical guidelines in paediatric dentistry: stainless steel preformed crowns for primary molars. Int J Paediatr Dent. 2006;16:15-23.

9 Parisay I, Ghoddusi J, Forghani M. A review on vital pulp therapy in primary teeth. Iran Endod J. 2015;10:6-15.

10 Al-Dlaigan, H Y. Pediatric dentists' choices of restorative materials for primary molars. Pakistan Oral Dent J. 1 2015; 35:83.

11 Kabaktchieva R, Gateva N. Vital pulpotomy in primary teeth with mineral trioxide aggregate (MTA). J IMAB. 2010; 15:102-8.

12 Kumar B. Pulpotomy in primary teeth: A review. JIADS. 2011;2:29-31.

13 Fuks AB. Vital pulp therapy with new materials for primary teeth: new directions and treatment perspectives. J Endod. 2008;34:518-24.

14 Angus C, Richard W. Handbook of pediatric dentistry. 4th ed. Canberra: Mosby Elsevier; 2013.

15 Meligy OAS El, Mahmoud SH. A comparative study of electrofulguration and formocresol pulpotomy techniques in primary teeth. Int J Surg Res Pract. 2014;2:2-5.

16 Manton DJ, Kan K. Survival of vital and non-vital deciduous molar teeth following survival of vital and non-vital deciduous molar teeth following pulpotomy. Aust Dent J. 2008;53:191.

17 Smith NL, Seale S, Nunn ME. Ferric sulfate pulpotomy in primary molars: A retrospective study. Am Acad Pediatr Dent. 2000;22:192-9.

18 Sultana A, Karim FAA, Sheihk AH, Wahiduzzaman M, Alam S, Hossain M. Better outcome in pulpotomy on primary molar with biodentine : A case report. Updat Dent Coll J. 2015;5:57-62.

19 Agarwal M, Das UM, Vishwanath D. A comparative evaluation of noninstrumentation endodontic techniques with conventional zoe pulpectomy in deciduous molars: An in vivo study. World J Dent. 2011;2:187-92.

20 Wright T, Cashion S, Hoover R. The esthetic stainless steel crown bridge: report of two cases. Am Acad Pediatr Dent. 1999;21:137-41.

21 Randall RC. Preformed metal crowns for primary and permanent molar teeth: review of the literature. Pediatr Dent. 2002;24:489-500.

22 Holan G, Fuks AB, Ketlz N. Success rate of formocresol pulpotomy in primary molars restored with stainless steel crown vs amalgam. Pediatr Dent. 2002;24:212-6. 